\title{
A RESSIGNIFICAÇÃO DO JUSNATURALISMO DE JOHN LOCKE A PARTIR DO CAPITALISMO HUMANISTA
}

\section{Victor Fernando Alves Carvalho ${ }^{1}$}

\section{Resumo:}

Este trabalho investiga em que medida a proposta do capitalismo humanista, formulada pelos juristas Ricardo Sayeg e Wagner Balera, ressignifica o pensamento do filósofo inglês do século XVII John Locke. Sayeg e Balera enfatizam a necessidade de que as forças do mercado sejam calibradas pela concretização multidimensional dos direitos humanos, com vistas à satisfação da dignidade da pessoa humana, o que se discute aqui como uma possível ressignificação do jusnaturalismo lockeano, por demandar um direito natural à fraternidade, para além dos direitos à liberdade e à igualdade. Por se focar numa fonte primária (o "Segundo tratado"), optou-se pelo método estrutural.

Palavras-chave: Capitalismo humanista; fraternidade; direitos naturais; propriedade; Locke.

\section{THE RESIGNIFICATION OF JOHN LOCKE'S JUSNATURALISM FROM HUMANIST CAPITALISM THEORY}

\begin{abstract}
:
This paper investigates to what extent the proposal of humanist capitalism, formulated by Ricardo Sayeg and Wagner Balera, resignifies the thinking of 17th century English philosopher John Locke. Sayeg and Balera emphasize the need for market forces to be calibrated by the multidimensional realization of human rights, with a view to satisfying the dignity of the human person, which is discussed here as a possible resignification of Lockean jusnaturalism, as it demands a natural right to fraternity, in addition to liberty and equality. Because it focused on a primary source (the "Second Treaty"), the structural method was chosen.
\end{abstract}

Keywords: Humanist capitalism; fraternity; natural rights; property; Locke.

\section{Considerações iniciais}

Sabe-se que o capitalismo venceu; enquanto modo de produção, até mesmo países que faziam parte do antigo bloco soviético hoje estão abertos à livre iniciativa e a uma economia de mercado. No entanto, o fracasso do socialismo real, ao mesmo tempo em que consagrou a vitória do bloco capitalista, apontou para a necessidade de humanização da economia. Afinal, de nada adianta que a livre iniciativa seja garantida a todas as pessoas, mas somente algumas sejam efetivamente livres para a negociação em igualdade de condições. Se

\footnotetext{
${ }^{1}$ Bacharel em Direito pela Universidade Federal de Sergipe (2018) e mestrando pelo Programa de PósGraduação em Direito da mesma instituição. Advogado. E-mail: victorfernandocarvalho@gmail.com
} 
não há um esforço pela superação de vulnerabilidades, o fracasso do socialismo e a vitória do capitalismo serão, na verdade, dois fracassos para a história da humanidade.

Nesse sentido, reflexões sobre um capitalismo de cunho mais humanista tem ganhado destaque no Direito há alguns anos. Sayeg e Balera (2011) propõem uma filosofia humanista para o direito econômico, no bojo da qual são plenamente reconhecidos o direito subjetivo natural à propriedade e o decorrente direito à livre iniciativa, mas ao mesmo tempo as forças naturais do mercado são calibradas pela concretização multidimensional (nas suas três dimensões) dos direitos humanos com vistas à satisfação universal da dignidade da pessoa humana. É uma proposta que se distingue do capitalismo liberal por não admitir a liberação descontrolada das forças do mercado; pelo contrário, parte da ideia de que um capitalismo que não respeite os direitos humanos não vale a pena.

Conforme Sayeg e Balera (2011), o capitalismo humanista é uma expressão do humanismo antropofilíaco, que supera o humanismo meramente antropocêntrico, por colocar no centro o ser humano não em sua dimensão individual, mas sim em sua dimensão relacional. Essa perspectiva permite a ressignificação da filosofia jusnaturalista de John Locke (1632-1704), pois demanda a existência de um direito natural à fraternidade, para além dos direitos naturais à liberdade e à igualdade, de que Locke já falava. Uma fraternidade apta a funcionar como medida de proporcionalidade entre a liberdade e a igualdade, e sob cujo manto as três dimensões dos direitos humanos estão amparadas, e não somente a primeira: os direitos humanos de primeira dimensão (liberdades negativas, internas e externas), os de segunda dimensão (liberdades positivas) e os de terceira dimensão (direitos de proteção).

John Locke (1978), em seu Segundo tratado sobre o governo, publicado em 1689, somente pensou nos direitos naturais individuais, que atualmente se classificam enquanto direitos humanos de primeira dimensão: as liberdades negativas, internas (crença e consciência) e externas (liberdade, igualdade, vida, propriedade). Sua filosofia liberal, ao defender a propriedade privada como direito natural (e a livre iniciativa dela decorrente), fundamentou a posterior apresentação do capitalismo como modo de produção inato ao ser humano; o regime de produção que mais respeita a natureza humana. O mérito de sua obra é indiscutível, pois sem o jusnaturalismo lockeano não há que se pensar nos direitos naturais à propriedade e à livre iniciativa. Contudo, as limitações do contexto histórico não permitiram que Locke fosse além, de modo a articular um direito natural à fraternidade. Por essa razão, a proposta do capitalismo humanista, fundamentada nos direitos subjetivos naturais não apenas 
à propriedade, liberdade e igualdade, mas também à fraternidade, ressignifica a filosofia lockeana, permitindo repensar o Segundo tratado sobre o governo para além das suas limitações de contexto:

[...] a fraternidade atuará, por assim dizer, como o maestro que rege o coro entre duas vozes: a da liberdade e a da igualdade, sob a clave melódica da dignidade humana e planetária que alberga o homem todo e todos os homens, irmanados por meio da concretização multidimensional dos direitos humanos [...] (SAYEG; BALERA, 2011, p. 183).

Feitas estas considerações iniciais, o propósito deste trabalho é investigar o conceito de capitalismo humanista, a partir da Sayeg e Balera (2011), apresentando-o como a resposta mais adequada às mazelas do atual sistema capitalista, na medida em que propõe a calibração das forças do mercado com a necessidade inafastável de concretização dos direitos humanos em todos os níveis. Afinal, a saída não é negar o capitalismo - o fracasso do bloco soviético deixa isso autoevidente -, mas sim aprimorá-lo, considerando os direitos humanos e o direito à fraternidade não como mera virtude moral, mas sim como “obrigação jurídica do Estado, da sociedade civil e dos homens livres para com todos e tudo, em especial para com os excluídos socialmente e para com o planeta" (SAYEG; BALERA, 2011, p. 215).

No entanto, em virtude de a proposta do capitalismo humanista ressignificar a filosofia lockeana, pretende-se inicialmente analisar a teoria jusnaturalista do filósofo inglês do século XVII (capítulo 2), para, em seguida, refletir-se sobre a inatidade do capitalismo enquanto regime econômico natural e sua compatibilidade com o humanismo antropofilíaco (SAYEG; BALERA, 2011, p. 214) (capítulo 3).

Quanto ao método de pesquisa, por se focar no presente trabalho num texto filosófico clássico a partir de sua fonte primária (o Segundo tratado de Locke), optou-se pelo método estrutural, no qual não apenas "se lê" a obra do autor, mas sobretudo se tenta traçar seu percurso meditativo, com vistas à compreensão da sua ordem de razões. Quando se trata da metodologia do pensar filosófico, tudo pode ser revelador: a predileção por um tema, a articulação das ideias, o apelo ao fragmento ou ao sistema. É necessário analisar com quem o filósofo está debatendo, a quem está dirigindo seu texto, com que objetivo e em quais condições. Tudo isso tem relevância. O método estrutural proporciona uma exegese precisa e uma análise rigorosa do texto filosófico, buscando-se identificar todos os movimentos do texto, e reconstruindo-lhe a estrutura (RODRIGUEZ, 2007, p. 18).

\section{0 jusnaturalismo lockeano}




\subsection{O momento histórico: do Locke passivo ao Locke revolucionário}

John Locke nasceu na Inglaterra de 1632. A fama alcançou-o como filósofo: o ano de 1689, no qual ele publicou muitos escritos, inclusive o Ensaio sobre o entendimento humano, foi emblemático da sua trajetória. Era, segundo Dunn (2003), puritano de sentimento, mas não de filosofia; o padrão de vida adotado por Locke situava-se num profundo senso de dever, mas muitas das suas concepções filosóficas teriam chocado qualquer puritano de 1632 . Na verdade, embora a família do filósofo não fosse suficientemente rica para lhe bancar uma vida de cavalheiro, ela mantinha ótimas relações com homens poderosos e influentes da época, o que o levou a participar das discussões políticas e filosóficas da Inglaterra.

Atualmente, historiadores e filósofos consideram Locke um pensador otimista, "cujo otimismo se baseava numa compreensão incompleta do que hoje compreenderíamos melhor" (DUNN, 2003, p. 10). Dunn pensa, pelo contrário, que se deve considerar Locke um pensador trágico,

[...] que compreendeu precocemente algumas das profundas contradições presentes na concepção moderna de razão e, desse modo, vê claramente uma parte da tragédia de nossas próprias vidas, que enxergamos ainda de maneira demasiado indistinta (DUNN, 2003, p. 10).

Os Dois tratados sobre o governo, publicados anonimamente em 1689, ecoavam o espírito do tempo em que o filósofo inglês viveu. Embora seja possível ver neles muitos temas da filosofia política, um deles se destaca: a afirmação de um direito de resistência à autoridade injusta. De fato, ambos os Tratados iam de encontro ao absolutismo das monarquias europeias e chegavam a delineações firmes das fronteiras em que a autoridade política do monarca deveria atuar. E é na afirmação de um direito de resistência que se capta, segundo Dunn (2003), uma das mudanças mais significativas no pensamento de Locke (influenciada, inclusive, pelo contexto revolucionário que ele estava vivenciando), pois inicialmente existia, por parte do filósofo inglês do século XVII, uma defesa de que o súdito deveria obedecer passivamente ao magistrado civil. Com efeito, o comentador ressalta que essa foi uma transformação importante em termos de compromisso político:

A mudança central em sua visão política, de um compromisso com a obediência passiva a uma reivindicação do direito de resistência à autoridade política injusta, foi uma mudança em sua concepção de como os homens podem e devem julgar o que pode preservar sua sociedade. Em vez de deixar esse julgamento inteiramente a cargo do governante e manter para o restante das pessoas apenas o direito de acreditar em suas próprias crenças religiosas (um direito do qual, de qualquer modo, ele não supunha que pudessem abdicar), Locke, nos Dois tratados, 
devolveu a todo ser humano adulto o direito e o dever de julgar como preservar a sociedade. (DUNN, 2003, p. 48-49, grifo ausente no original).

Essa mudança de perspectiva deve-se, segundo Dunn (2003), não só à influência de Anthony Ashley Cooper, terceiro conde de Shaftesbury, proeminente Whig com quem Locke mantinha relações próximas, mas também à própria experiência política pela qual o filósofo passou no século XVII. A experiência revolucionária foi suficientemente intensa para que, anos depois, se tornasse impossível negar o radicalismo com que Locke apresenta as suas ideias nos Dois tratados. Radicalismo que não significa, lembra Dunn (2003), que Locke não analisou as implicações práticas da sua teoria, mas que também é proveniente em grande parte da resposta de Locke aos desafios de Robert Filmer, para quem toda autoridade entre os seres humanos (o pai sobre a família, o monarca sobre o reino) compartilhava a mesma essência e era proporcionada diretamente por Deus.

Considerando-se tantos séculos de absolutismo monárquico e de abusos do Antigo Regime, a formulação do direito de resistência ${ }^{2}$ elevou Locke à categoria dos filósofos revolucionários, como Jean-Jacques Rousseau e Barão de Montesquieu; intelectuais cujas ideias moldaram as Revoluções Liberais dos séculos XVII e XVIII:

Onde quer que a lei termine, a tirania começa, se se transgredir a lei para dano de outrem. E quem quer que em autoridade exceda o poder que lhe foi dado pela lei, e faça uso da força que tem sob as suas ordens para levar a cabo sobre o súdito o que a lei não permite, deixa de ser magistrado e, agindo sem autoridade, pode sofrer oposição como qualquer pessoa que invada pela força o direito de outrem. (LOCKE, 1978, p. 114, grifo ausente no original).

O comentador Richard Ashcraft defende, inclusive, que o fornecimento de uma justificativa para uma resistência organizada contra a autoridade ilegítima do rei é "o objetivo político mais importante que Locke pretendia realizar por meio da composição dessa obra [o Segundo tratado sobre o governo]" (ASHCRAFT, 2011, p. 279). Este tipo de interpretação não é descabida, tendo em vista que o Segundo tratado exerceu influência decisiva sobre os movimentos revolucionários da época moderna (MELLO, 2006, p. 84), de tal modo que se pode apontar esta obra como uma fundamentação ex post facto da Revolução Gloriosa, com a legitimidade da deposição de Jaime II por Guilherme de Orange e pelo Parlamento justificada pelo direito de resistência (MELLO, 2006, p. 82).

\footnotetext{
${ }^{2} \mathrm{Na}$ verdade, Locke não foi completamente original na formulação do direito de resistência. "A doutrina do direito de resistência não era recente e sua origem remontava às guerras de religião, quando os escritores políticos calvinistas, denominados monarcomaci, conclamavam o povo a resistir aos atos ilegais dos príncipes católicos" (MELLO, 2006, p. 88). O que o filósofo inglês faz é ressignificar a doutrina da resistência para o seu tempo, cultivando o fermento para as revoluções liberais dos séculos XVII e XVIII.
} 
De todo modo, um texto filosófico sempre abre espaço para mais de uma interpretação, e Locke não escapou à regra. Algumas das suas vias interpretativas, inclusive, põem o liberalismo e o individualismo lockeanos em questão. De certo modo, a multiplicidade de interpretações tem razão de ser: o filósofo inglês nem sempre conceituou com exatidão as expressões de que fazia uso no seu Segundo tratado sobre o governo. No próximo tópico, faz-se uma discussão sobre algumas categorias de análise da obra de Locke, com vistas a compreender o percurso meditativo do autor e a ordem de argumentos na sua teoria política moderna.

\subsection{Individualidade, sociabilidade e propriedade em Locke}

Na linguagem lockeana, o termo "indivíduo" não é sistematicamente empregado. Polin destaca que, no entanto, há uma relação conceitual entre indivíduo, liberdade e razão:

\footnotetext{
o que caracteriza a princípio um homem enquanto indivíduo e o torna distinto e independente de todos os outros é sua liberdade natural. [...] a liberdade efetua a individualização que a consciência reconhece e estabelece, se a liberdade já não fosse, ela própria, uma função do pensamento racional e, consequentemente, da consciência. A liberdade da pessoa não pode ser senão aquela de um ser dotado de razão. (POLIN, 1980, p. 133-134, grifo ausente no original).
}

Nesse sentido, a liberdade natural individualiza o homem. Todos se afirmam como iguais entre si, haja vista que são naturalmente dotados das mesmas faculdades. A liberdade natural, no entanto, não basta, pois a individualização precisa ser reconhecida pela consciência. Afinal, apenas um ser racional pode ter liberdade. Desse modo, a consciência estabelece e reconhece a individualização, cuja causa é a própria liberdade. A pessoa, por sua vez, é o indivíduo quando considerado no âmbito jurídico. Isto é, é o indivíduo dotado de direitos e deveres e capaz de viver segundo uma lei, uma vez que, tendo atingido a idade da razão (a idade em que ela se encontra plenamente desenvolvida), pode ser responsabilizado pelas suas ações.

Ademais, cada indivíduo tem a propriedade da sua própria pessoa. Disso decorre que o trabalho das suas mãos - o esforço do seu corpo - não deixa de constituir propriedade sua. De fato, Polin (1980) salienta que todo homem, em Locke, nasce com um direito duplo: o direito à liberdade da sua pessoa e o direito à propriedade daquilo que a sua pessoa modifica. “Ora, são precisamente estes direitos naturais que, para Locke, definem o indivíduo, que são reconhecidos tradicionalmente como os critérios do individualismo" (POLIN, 1980, p. 135). 
São estes os direitos inalienáveis (embora o termo "inalienável” não apareça no vocabulário lockeano).

A leitura de Polin (1980) renova as interpretações acerca do individualismo lockeano, considerando que a maneira como Locke concebe o indivíduo acarreta que este é essencial e efetivamente um ser social. Afinal, para Locke Deus não dotou os homens da faculdade do entendimento e do poder da palavra (os principais meios de comunicação) por acaso. Além disso, a vida isolada condena o homem à miséria, e ele percebe racionalmente que a vida em sociedade lhe fornece todos os auxílios.

Assim, não apenas a individualidade, mas também a sociabilidade torna-se obrigação para o ser humano. É quase uma leitura aristotélica de Locke, pois para Aristóteles a natureza humana realiza-se plenamente quando participamos da pólis (ARISTÓTELES, 2006). Afinal, “a natureza não faz nada em vão, e os seres humanos, diferentemente dos outros animais, possuem a faculdade da linguagem" (SANDEL, 2018, p. 243), pela qual se pode discernir e deliberar sobre o bem, sobre a vida boa. Assim, apenas por meio da associação política o homem pode exercitar a faculdade humana da linguagem, "porque somente em uma pólis deliberamos com os demais sobre justiça e injustiça e sobre a natureza da vida boa" (SANDEL, 2018, p. 243).

De todo modo, é impossível não enxergar a lógica burguesa na teoria lockeana, pois a formação da sociedade por meio do contrato social ${ }^{3}$ visa à proteção dos homens na qualidade de proprietários. Na lógica de Locke, "ser proprietário de sua liberdade, de seu corpo, de seu trabalho [...] implica já ser um proprietário, quer dizer uma pessoa civil com direitos jurídicos bem definidos e isto basta para ser membro do corpo político" (POLIN, 1980, p. 145). Os mendigos e os "vagabundos", nesse sentido, ficariam excluídos do corpo político, por não serem proprietários por meio do trabalho. Essa interpretação de Polin (1980) não é descabida dentro da teoria lockeana sobre a propriedade.

\footnotetext{
${ }^{3} \mathrm{Na}$ filosofia lockeana a lei natural não some no estado civil; apenas o direito de o próprio indivíduo interpretar a lei natural e o poder de ele mesmo assegurar-se de sua execução é que são abandonados em prol da Commonwealth. Dito isso, ser livre na comunidade política significa: "A liberdade civil consiste em não viver senão sob o poder legislativo a que se consentiu incorporando-se à Commonwealth, e em só obedecer às leis estabelecidas por este poder legislativo com o objetivo de cumprir a missão que lhe foi confiada. Ser livre na comunidade significa obedecer à lei geral, comum a todos, onde quer que ela exista e agir segundo a sua vontade em todos os lugares onde a lei se cale" (POLIN, 1980, p. 150). No entanto, quando os governantes quebram o trust, agindo contra o princípio para o qual a sociedade política foi criada, o direito de interpretar e executar a lei natural não é retomado por cada indivíduo isoladamente, mas pelo povo, no exercício coletivo do direito de resistência.
} 
De fato, essa teoria é uma das inovações teóricas mais singulares do pensamento do filósofo inglês. Segundo Gough (1980), Locke preocupava-se em deixar claro que a instituição da propriedade privada não devia sua existência ao estado de sociedade. $\mathrm{Na}$ verdade, para o filósofo inglês do século XVII, tal instituição já existia no estado de natureza. O principal dever do governo, nesse sentido, correspondia a protegê-la de qualquer agressão. O ponto de vista anterior a Locke, no entanto, era mais hobbesiano, no sentido de que a propriedade resultaria do contrato social, sendo na verdade uma outorga estatal: posterior ou simultânea à formação do Estado. John Locke coloca a propriedade enquanto direito natural: “o Estado não criou a propriedade, sendo antes criado para protegê-la" (GOUGH, 1980, p. 166).

Gough (1980) defende que a teoria lockeana sobre a propriedade não apenas a inclui no rol dos direitos naturais, como também é marcadamente individualista. Isso se deve ao fato de que, para Locke, todo indivíduo tem uma propriedade primordial: a propriedade de sua própria pessoa. Como consequência, o trabalho das suas mãos, o esforço do seu corpo não deixa de constituir propriedade sua. Ademais, na teoria lockeana, não é permitido ao governo apropriar-se da propriedade dos súditos sem o seu devido consentimento. Segundo Gough (1980), essa posição era previsível, haja vista que, na Inglaterra em revolução, qualquer tentativa governamental de aumentar os impostos por caminhos inconstitucionais sofria intenso repúdio.

Todavia, ao mesmo tempo, Gough (1980) ressalta que se deve ter cautela quando se fala da extensão do individualismo de Locke. Além de este afirmar que o mundo foi dado por Deus a Adão e a todos os homens em comum, indo de encontro ao princípio do direito divino dos monarcas, o pensador inglês do século XVII também traça limites para a apropriação (que gera a propriedade genuína). O "servir-se" da natureza não pode ocasionar desperdício; nesse sentido, a apropriação deve abranger aquilo de que o indivíduo efetivamente precisa para a sua subsistência. Se se apoderar de mais, estará se apropriando do que pertence aos outros.

Críticas a Locke também vinham, segundo Gough (1980), dos juristas. Afinal, como conceber que tanto a propriedade da própria pessoa quanto a propriedade dos bens móveis e imóveis devem receber a mesma classificação conceitual? De fato, isso talvez se devesse a um uso não rígido do termo "propriedade". O que Locke defendia, no entanto, é que o trabalho "é somente o estágio final no processo de criação de propriedade" (GOUGH, 1980, p. 169). Isto 
é, ao passo que a propriedade dos bens distingue-se pela subsequência, a propriedade da própria pessoa distingue-se pela inatidade.

Gough (1980) também afirma que alguns autores encontram certa incoerência moral na teoria lockeana sobre a propriedade. De fato, se quem produz, no sistema capitalista, é o trabalhador, por que o que ele produz não é considerado propriedade dele, mas sim do patrão? O comentador esclarece que o sistema político de Locke legitima tal ideia à medida que considera não só o trabalho uma propriedade alienável (e, portanto, vendível por salários), mas também o dinheiro um instrumento de apropriação em larga escala. Ora, Locke admite que a invenção do dinheiro permitiu significativas acumulações de propriedade, mas não questiona a sua desigual distribuição. Ao Estado caberia somente a função de proteger as propriedades: nunca de interferir nelas sem o devido consentimento do proprietário.

Ainda assim, Gough (1980) ressalta que "Locke não era um defensor do laissezfaire, nem acreditava, como muitos economistas do início do século XIX, que as relações econômicas se equilibrariam e se ajustariam automaticamente" (1980, p. 176). Com efeito, Locke acreditava que as relações comerciais deveriam ser regulamentadas.

Em relação ao controle político, o comentador diz que, para Locke, devem fazer parte da vida política da sociedade civil apenas os proprietários. Desse modo, a condição para que o filho receba a herança do seu pai é que aquele aceite o governo legal (que se voltou justamente para a proteção aos bens do pai). Na verdade, "muitos ingleses acreditavam, como Locke, que a proteção à propriedade era a principal, senão a única, tarefa do Estado" (GOUGH, 1980, p. 173). Deles Locke diverge à medida que defende a existência da propriedade privada ainda no estado de natureza.

O efeito colateral da teoria lockeana é, segundo Gough (1980), direcionar o poder político para as mãos de uma minoria proprietária, esperando que esta exerça o seu poder imparcialmente no interesse geral. Tal linha teórica parece atualmente inadequada e ingênua, mas Gough destaca que "ela não o era mais que as outras dos seus contemporâneos" (1980, p. 176). Somente com a Revolução Industrial desenvolveu-se um marco histórico para que os homens começassem a modificar os seus pontos de vista sobre a organização econômica da sociedade civil.

Percebe-se, assim, que o modo (por vezes confuso) como Locke usou o termo "propriedade" abre espaço para muitos questionamentos. O filósofo inglês do século XVII com frequência o usa indistintamente (sem definir, quando o emprega, se o faz no sentido 
comum ou no sentido estrito). Além disso, no que diz respeito à conquista, pode-se ver ainda com mais clareza, segundo Gough (1980), a crença lockeana na inviolabilidade da propriedade privada, uma vez que o conquistador, na teoria de Locke, não adquire qualquer direito sobre os bens dos conquistados.

Não obstante a existência de alguns obstáculos para a coerência do conjunto da teoria de Locke sobre a propriedade, o comentador salienta:

Se tivermos que admitir um direito natural de propriedade, este precisaria basear-se
no mesmo tipo de argumentos que também podem ser utilizados na defesa da
liberdade como um direito natural. Este não será nenhum direito "absoluto" do
indivíduo possuir, ou agir, sem consideração para com seus vizinhos. Ele se
exercerá indispensavelmente dentro do quadro social e por este será
condicionado. [...] podemos sentir que Locke chegou a conclusões corretas, mesmo
sua argumentação sendo falha e sua trajetória confusa. (GOUGH, 1980, p. 182, grifo
ausente no original).

De fato, no estágio em que se encontra a humanidade, a desconsideração do direito à propriedade resultaria em consequências indesejáveis. Com efeito, Gough (1980) pensa que a teoria de Locke proporcionou avanços não só para o pensamento filosófico sobre a propriedade, mas também para a maneira como os diversos ordenamentos jurídicos a trataram. Não obstante as suas falhas, é indubitável, conclui Gough (1980), que o pensamento do filósofo inglês do século XVII contribuiu sensivelmente para a evolução constitucional do Estado de Direito, particularmente no que diz respeito ao conceito de propriedade.

Ao analisar o problema do direito de propriedade em Locke, Dunn (2003) enfatiza a questão do mérito. Locke considera, segundo Dunn (2003), que tanto a razão humana quanto a Revelação divina apontam para a mesma conclusão: a terra e tudo o que há nela pertencem a todos os homens em comum. A questão é, na verdade, saber como os homens passam a ter um direito privado sobre qualquer parte dela, e a resposta a tal questão encontra-se, para Locke, na propriedade humana do trabalho. "O trabalho é o que distingue o que é possuído em caráter privado do que é mantido em comum; o trabalho do corpo e das mãos de um homem" (DUNN, 2003, p. 56). O indivíduo, ao misturar a propriedade do trabalho com objetos materiais (colhendo, por exemplo), adquire o direito privado sobre o que trabalhou. E é para ser trabalhada, afinal, que serve a natureza; nunca para ser desperdiçada. Assim, quanto mais se trabalha, mais se é meritório ter propriedades.

Portanto, uma interpretação eminentemente meritocrática da teoria lockeana sobre a propriedade não é descabida. Nas palavras de Locke:

Embora a terra e todas as criaturas inferiores sejam comuns a todos os homens, cada homem tem uma propriedade em sua própria pessoa; a esta ninguém tem qualquer 
direito senão ele mesmo. O trabalho do seu corpo e a obra das suas mãos, pode dizer-se, são propriamente dele. Seja o que for que ele retire do estado que a natureza lhe forneceu e no qual o deixou, fica-lhe misturado ao próprio trabalho, juntando-se-lhe algo que lhe pertence, e, por isso mesmo, tornando-o propriedade dele. Retirando-o do estado comum em que a natureza o colocou, anexou-lhe por esse trabalho algo que o exclui do direito comum de outros homens. Desde que esse trabalho é propriedade exclusiva do trabalhador, nenhum outro homem pode ter direito ao que se juntou, pelo menos quando houver bastante e igualmente de boa qualidade em comum para terceiros. (LOCKE, 1978, p. 45-46, grifo ausente no original).

Posto dessa forma, o direito de propriedade decorrente diretamente do trabalho não precisava, para Locke, da regulação governamental, uma vez que, a seu ver, o trabalho só faz bem aos homens. Ademais, Dunn (2003) destaca que o termo "propriedade" refere-se, em Locke, às titularidades humanas (vida, liberdade, posses materiais), cuja proteção cabe ao governo. Todos têm direito à vida e à liberdade; as posses materiais, por sua vez, constituem produto direto do trabalho. O que levou Locke a dedicar todo um capítulo do Segundo tratado para discutir a propriedade no sentido das posses foi, segundo Dunn (2003), a intenção de negar o direito, por parte de um monarca, de interferir arbitrariamente nas posses dos súditos, sem o consentimento destes. Ou seja, este comentador concorda com Ashcraft no sentido de que o fornecimento de uma justificativa para uma resistência organizada contra a autoridade ilegítima do rei é "o objetivo político mais importante que Locke pretendia realizar por meio da composição dessa obra [o Segundo tratado sobre o governo]" (ASHCRAFT, 2011, p. 279).

\subsection{A conveniência da filosofia lockeana para a defesa do capitalismo}

Como visto, Locke afirmava os direitos à vida, liberdade, igualdade e propriedade já no estado natural, o que o consagrou como um jusnaturalista da modernidade, crítico ferrenho do absolutismo, por justificar a formação da sociedade política ante a necessidade exclusivamente de garantia dos direitos naturais individuais, expostos aos inconvenientes ínsitos à ausência de magistrados imparciais no estado de natureza:

\footnotetext{
Do que ficou dito é evidente que a monarquia absoluta, que alguns consideram o único governo do mundo, é, de fato, incompatível com a sociedade civil, não podendo por isso ser uma forma qualquer de governo civil, porque o objetivo da sociedade civil consiste em evitar e remediar os inconvenientes do estado de natureza que resultam necessariamente de poder cada homem ser juiz em seu próprio caso, estabelecendo-se uma autoridade conhecida para a qual todos os membros dessa sociedade podem apelar por qualquer dano que the causem ou controvérsia que possa surgir, e à qual todos os membros dessa sociedade terão de obedecer. Onde quer que existam pessoas que não tenham semelhante autoridade a que recorrerem para decisão de qualquer diferença entre elas, estarão tais pessoas
} 
no estado de natureza; e assim se encontra qualquer príncipe absoluto em relação aos que estão sob seu domínio. (LOCKE, 1978, p. 68, grifo ausente no original).

É controversa, no entanto, a extensão desse jusnaturalismo individualista. Como visto, a leitura de Polin (1980) renova as interpretações acerca do individualismo lockeano, eis que, considerando a faculdade da linguagem, a sociabilidade vincula-se ao homem como uma obrigação, tanto quanto a individualidade. Todavia, na medida em que a sociedade política é formada para a proteção dos homens enquanto proprietários, ideais de solidariedade e fraternidade são fragilizados, pois mendigos e "vagabundos" ficariam excluídos do corpo político. Já Gough (1980), apesar de ler a teoria lockeana como marcadamente individualista, enfatiza a necessidade de cautela nessa classificação, eis que o próprio Locke condenava o desperdício como uma ofensa à propriedade comunal. De todo modo, reconhece que a teoria lockeana sobre a propriedade tem um efeito colateral: direcionar o poder político para as mãos de uma minoria proprietária, esperando que esta exerça o poder no interesse geral. Dunn (2003), por sua vez, enfatiza uma interpretação eminentemente meritocrática, tendo em vista que Locke fundamenta a propriedade privada a partir do esforço das próprias mãos e do trabalho do próprio corpo (primeira propriedade do indivíduo), reiterando a fala de Ashcraft de que o direito de resistência contra abusos do rei que violam a propriedade privada era o chamado central do Segundo tratado.

Independentemente da feição com que se queira classificar Locke, duas coisas são certas.

A primeira é que somente graças ao jusnaturalismo lockeano consolidou-se a concepção de que "o homem enquanto tal tem direitos, por natureza, que ninguém (nem mesmo o Estado) lhe pode subtrair, e que ele mesmo não pode alienar” (BOBBIO, 2004, p. 28). Uma ideia que se arraigará no direito moderno de tal modo que a própria Declaração Universal dos Direitos Humanos de 1948 afirma, em seu art. 1": "Todos os seres humanos nascem livres e iguais em dignidade e direitos"; ênfase em: "nascem livres e iguais", tal como Locke falava: "sendo este [o estado de natureza] um estado de perfeita liberdade para ordenarlhe as ações [...] estado também de igualdade, no qual é recíproco qualquer poder e jurisdição" (LOCKE, 1978, p. 35).

A segunda é que o modo de produção capitalista é, por vocação, "estruturado na filosofia de John Locke, que reconhece o direito subjetivo natural de propriedade como um direito inato do homem e de todos os homens" (SAYEG; BALERA, 2011, p. 146). A filosofia 
hobbesiana era incompatível com o capitalismo nascente, tendo em vista que Thomas Hobbes não defendia a propriedade como um direito natural, sendo mera concessão do Leviatã. Não à toa, Locke, e não Hobbes, foi o intelectual mais conveniente para a burguesia revolucionária, apesar de ambos serem ingleses e praticamente contemporâneos:

\begin{abstract}
A sociedade burguesa, que no tempo de Hobbes já luta para se afirmar, estabelece a autonomia do proprietário para fazer com seu bem o que bem entenda. Na Idade Média, a propriedade era um direito limitado, porque havia inúmeros costumes e obrigações que a controlavam. Por exemplo, o senhor de terras não podia impedir o pobre de colher espigas, ou frutas, na proporção necessária para saciar a fome. [...] Hobbes reconhece o fim das velhas limitações feudais à propriedade - e nisso ele está de acordo com as classes burguesas, empenhadas em acabar com os direitos das classes populares à terra comunal ou privada - mas, ao mesmo tempo, estabelece um limite muito forte à pretensão burguesa de autonomia: todas as terras e bens estão controlados pelo soberano. (RIBEIRO, 2006, p. 73, grifos nossos).
\end{abstract}

Com efeito, o fato de Hobbes colocar limitações à pretensão burguesa de plena autonomia perante o Estado afastou-o dos revolucionários, dependentes da consolidação do capitalismo para junto se consolidarem enquanto classe. Nesse sentido, é inevitável concluir pela pertinência da filosofia lockeana à defesa do capitalismo, e mais: à afirmação do capitalismo enquanto regime econômico ínsito ao ser humano. Afinal, estando o capitalismo baseado no direito subjetivo natural à propriedade e no decorrente direito à livre iniciativa, outra alternativa não resta que não concluir por sua inatidade (dentro do quadro teórico aqui mobilizado, por óbvio). "Logo, o capitalismo é inato ao homem e a todos os homens, correspondendo a uma perspectiva subjetiva natural do direito de propriedade estruturada na filosofia de Locke" (SAYEG; BALERA, 2011, p. 146).

Superada esta questão, no entanto, surge outra, ainda mais urgente, neste século em que grandes potências flertam com o Armagedom nuclear e as mazelas do neoliberalismo voraz ficam cada vez mais patentes: é possível compatibilizar o capitalismo com um humanismo antropofilíaco e integral? Que proposta é capaz de contornar os excessos do capitalismo neoliberal, compatibilizando-o com os direitos humanos em todas as suas dimensões e garantindo o pleno respeito à dignidade da pessoa humana? É viável um capitalismo humanista, de matriz fraternal? São essas as questões que nos conduzem ao próximo capítulo.

30 capitalismo humanista enquanto ressignificação da filosofia lockeana: ênfase na fraternidade 
No ordenamento jurídico brasileiro, a livre iniciativa está positivada na Constituição Federal, em dois momentos distintos (artigo $1^{\circ}$, inciso IV, e artigo 170, caput), estruturada no direito subjetivo natural de propriedade. Assim, "ela existe com ou sem Código Civil e mesmo com ou sem Constituição que a assegurem" (SAYEG; BALERA, 2011, p. 148), afinal é indicada pela lei natural. O próprio direito natural, contudo, relativiza o direito subjetivo natural de propriedade, pois, como vimos, o jusnaturalismo lockeano classificava o desperdício como um atentado à propriedade comum dos homens. No mesmo raciocínio, a Constituição Federal positiva o respeito à função social da propriedade, sobretudo quando prevê, no artigo $5^{\circ}$, inciso XXIII, que a propriedade atenderá a sua função social, e no artigo 170, inciso III, que a ordem econômica observará o princípio da função social da propriedade.

A pergunta central, no entanto, é: em que medida é possível fazer incidir sobre o capitalismo o humanismo antropofilíaco, que coloca os seres humanos numa teia relacional? É possível impor ao capitalismo os contornos limitativos dos direitos humanos? Em que sentido é possível falar de uma lei natural da fraternidade que ressignifica e amplia o jusnaturalismo moderno e que enquadra a própria ordem capitalista?

É um desafio de relevância, eis que "o liberalismo e sua transposição para o direito são convenientes naquelas ordens soberanas em que não há graves déficits de concretização desses direitos [humanos de segunda e terceira dimensões]" (SAYEG; BALERA, 2011, p. 164), afinal na ordem capitalista neoliberal a tendência é sempre que os ricos fiquem mais ricos e os pobres fiquem mais pobres. Um humanismo de cunho antropofilíaco não admite indiferença à pobreza e aos destinos do planeta; pelo contrário, exige que a devida atenção aos direitos humanos de segunda e terceira dimensões supere preocupações de ordem exclusivamente financeira. Apesar de a ordem capitalista ser exitosa no respeito aos direitos humanos de primeira dimensão, em especial a garantia das liberdades, "não existe na economia de mercado uma compaixão que consagre a fraternidade, já que seu ambiente é o estado selvagem da natureza - colocado sob o domínio da lei da seleção natural pela qual sobrevive o apto e descarta-se o inapto" (SAYEG; BALERA, 2011, p. 169). Desse modo, o humanismo antropofilíaco impõe ao regime capitalista a tarefa de avançar para além do neoliberalismo, rumo a uma economia humanista de mercado e, consequentemente, a uma análise humanista do Direito Econômico.

Um exemplo concreto desse capitalismo humanista, "em resposta ao enfoque puramente neoliberal da economia de mercado - que não se interessa pelo destino da 
humanidade nem muito menos pelo da enorme massa de excluídos" (SAYEG; BALERA, 2011, p. 177), é a ideia da transferência de renda, como o Bolsa Família. O Programa Bolsa Família foi criado pela Lei 10.836/2004, destinado às ações de transferência de renda mediante certas condicionalidades. Resultou, em verdade, da unificação de diversos Programas, como o Bolsa Escola, o Bolsa Alimentação e o Auxílio-Gás. A execução do Programa sempre foi voltada à instituição de uma renda básica de cidadania, conforme ensina Garcia (2015, p. 303): um mínimo vital.

Nesse sentido, um capitalismo inspirado pelo humanismo antropofilíaco demanda assegurar a todas as pessoas um mínimo indispensável à satisfação da dignidade humana. É esta a essência do capitalismo humanista: é um capitalismo antropofilíaco, trocando em miúdos, um capitalismo que respeita os direitos humanos em todas as suas dimensões, não se restringindo à garantia das liberdades individuais internas e externas. Colocada nesses termos, esta solução tem o seguinte potencial:

[...] consagra a liberdade e a igualdade na medida da proporcionalidade fixada pela
fraternidade, numa cadeia de inter-adensamento em prol do homem todo e de todos
os homens --, um capitalismo entendido e regido pela ótica dos direitos humanos
multidimensionalmente adensados e considerados para o fim da satisfação da
dignidade da pessoa humana e do planeta. [...] a fraternidade atuará, por assim
dizer, como o maestro que rege o coro entre duas vozes: a da liberdade e a da
igualdade, sob a clave melódica da dignidade humana e planetária que alberga
o homem todo e todos os homens, irmanados por meio da concretização
multidimensional dos direitos humanos [...]. (SAYEG; BALERA, 2011, p. 183,
grifos nossos).

Pode-se concluir, portanto, que a proposta do capitalismo humanista, ao enfatizar a dimensão fraternal, ressignifica a filosofia lockeana. As liberdades individuais, internas (de consciência) e externas (direito subjetivo natural de propriedade), correspondem aos direitos humanos de primeira dimensão, fundamentados no jusnaturalismo moderno de John Locke, sem o qual a ideia de individualidade não teria repercutido na modernidade (BOBBIO, 2004). No entanto, em virtude das limitações da época, o jusnaturalismo lockeano vai até aí. Ampliando a perspectiva, pela consideração de uma verdadeira Lei Universal da Fraternidade, as liberdades individuais seriam apenas uma primeira dimensão. Ainda sob a Lei Universal da Fraternidade, a evolução do espírito conduz aos direitos humanos de segunda dimensão (os direitos sociais, tais como trabalho, moraria, saneamento básico, saúde, alimentação, educação e lazer), ante a crescente percepção de que todos os seres humanos estão numa teia de interconexão, o que gera responsabilidade e necessidade de cuidado de uns pelos outros. Por fim, a Lei Universal da Fraternidade abarca os direitos humanos de terceira dimensão: 
direitos de proteção e preservação da humanidade como um todo, do planeta portanto (meio ambiente, paz).

Essas duas últimas dimensões de direitos humanos - a segunda e a terceira - não foram incluídas nas reflexões de Locke. Vivendo no século XVII, e impregnado pelo iluminismo e individualismo, o filósofo só vislumbrou os direitos naturais individuais. (SAYEG; BALERA, 2011, p. 189, grifo ausente no original).

Essa tríade - direitos humanos de primeira dimensão, de segunda dimensão e de terceira dimensão - se expressa, sob a Lei Universal da Fraternidade, como um direito natural privado, um direito natural público, e um direito natural universal. ${ }^{4}$ A ordem capitalista é conduzida pelo humanismo antropofilíaco quando há esse respeito aos direitos humanos no sentido multidimensional, e não apenas no sentido exclusivo das liberdades individuais negativas. "Considerada sua característica multidimensional, a presente perspectiva evolui ao repensar a filosofia de Locke", buscando-se "avançar no sentido de ponderar os direitos além dos individuais, incluindo também as liberdades positivas e os interesses universais" (SAYEG; BALERA, 2011, p. 189-190). Este pensamento não contraria a filosofia lockeana, mas a aprimora, a partir da Lei Universal da Fraternidade, com vistas à satisfação universal da dignidade da pessoa humana. Não à toa, é possível, sim, considerar o capitalismo humanista a resposta mais adequada às mazelas do atual sistema capitalista, na medida em que propõe a calibração das forças do mercado com a necessidade inafastável de concretização dos direitos humanos, em todos os seus níveis. Em todos os seus níveis porque "sem liberdade haverá a tirania da igualdade. Sem igualdade, a tirania da liberdade. E, sem fraternidade, liberdade e igualdade são incompatíveis" (SAYEG; BALERA, 2011, p. 119, grifo ausente no original).

É de se destacar que a corrente teórica do capitalismo humanista fornece uma doutrina jurídica compatível com as disposições expressas da Constituição Federal de 1988, eis que o constituinte não só fez a opção pelo regime capitalismo, ao consagrar o direito à propriedade privada e à livre iniciativa, mas também apontou como finalidade da ordem econômica assegurar uma existência digna. Segundo Machado (2014, p. 147-148), o capitalismo humanista reflete o "compromisso constitucional preambular de uma sociedade fraterna e o objetivo fundamental de construção de uma sociedade solidária". Nesses termos, essa proposta concilia o capitalismo com a finalidade última de todo o ordenamento - a garantia da dignidade da pessoa humana (CASTILHO, 2013), razão pela qual "o direito

\footnotetext{
4"Logo, constata-se, nessa linha de aprofundamento do fenômeno jurídico, em sintonia com uma concepção humanista, de raiz tomista, que, mais do que indivíduos, somos pessoas e como tais, irmãos, todos integrantes da mesma família humana, pois concebidos com idêntica dignidade" (MACHADO, 2014, p. 119).
} 
econômico já não pode mais ser analisado de forma estanque e à dogmática jurídica reservase a tarefa de integrá-lo com a teoria dos direitos humanos, sendo este um importante caminho cujo trilhar ora se inicia” (CASTILHO, 2013, p. 79).

\section{Considerações finais}

O presente trabalho se propôs a pensar o capitalismo humanista a partir de um dos tantos vieses pelos quais ele pode ser pensado: como uma ressignificação e revalorização da filosofia lockeana. Viu-se que, independentemente da feição com que se queira categorizar o filósofo inglês do século XVII, é certo não somente que graças a Locke se consolidou a concepção dos direitos inalienáveis a todo ser humano pelo simples fato de ter nascido ser humano, mas também que a ordem capitalista deve sua legitimação ao jusnaturalismo lockeano, na medida em que este fundamenta a propriedade como direito subjetivo natural de todos os seres humanos. Contudo, diante dos excessos do neoliberalismo voraz na contemporaneidade, a reflexão do filósofo inglês pede atualização, eis que se mostrou necessário ir além dos direitos individuais e amadurecer um elemento que funcione como maestro do coro entre a liberdade e a igualdade. Esse elemento é a fraternidade, apto a conduzir a ordem capitalista na perspectiva do humanismo antropofilíaco, que propõe sejam as forças do mercado calibradas pela concretização multidimensional dos direitos humanos, com vistas à satisfação universal da dignidade da pessoa humana (um exemplo concreto são os programas de renda mínima e transferência de renda, como visto). De todo modo, à medida que se percebe a característica multidimensional dos direitos humanos, fica clara a necessidade de se repensar Locke, avançando-se para além das liberdades individuais, rumo às liberdades sociais e, por óbvio, aos interesses de toda a humanidade.

\section{Referências bibliográficas}

ARISTÓTELES. A Política. Trad. Nestor Silveira Chaves. São Paulo: Escala Educacional, 2006 (Série Filosofar).

ASHCRAFT, Richard. A filosofia política. In: CHAPPELL, Vere (org.). Locke. Aparecida: Ideias \& Letras, 2011.

BOBBIO, Norberto. A era dos direitos. Trad. Carlos Nelson Coutinho. Rio de Janeiro: Elsevier, 2004.

CASTILHO, Ricardo. Refundação do Direito Econômico sob a égide dos Direitos Humanos: o capitalismo humanista. In: CAMPELLO, Lívia Gaigher Bósio; SANTIAGO, Mariana 
Ribeiro (org.). Capitalismo Humanista e Direitos Humanos: Estudos em Homenagem aos Professores Ricardo Sayeg e Wagner Balera. Florianópolis: Conceito Editorial, 2013. P. 6780.

DUNN, John. Locke. Trad. Luiz Paulo Rouanet. São Paulo: Loyola, 2003.

GARCIA, Gustavo Filipe Barbosa. Curso de direito da seguridade social. Rio de Janeiro: Forense, 2015.

GOUGH, J. W. A teoria de Locke sobre a propriedade. In: QUIRINO, Célia Galvão; SOUZA, Maria Teresa Sadek R. de. O pensamento político clássico; Maquiavel, Hobbes, Locke, Montesquieu, Rousseau. São Paulo: T. A. Queiroz, 1980, p. 165-182.

LOCKE, John. Carta acerca da tolerância; Segundo tratado sobre o governo; Ensaio acerca do entendimento humano. Trad. Anoar Aiex; E. Jacy Monteiro. São Paulo: Abril, Cultural, 1978 (Os pensadores).

MACHADO, Carlos Augusto Alcântara. A garantia constitucional da fraternidade: constitucionalismo fraternal. 2014. Tese (Doutorado em Direito) - Pontifícia Universidade Católica de São Paulo, São Paulo.

MELLO, Leonel Itaussu Almeida. John Locke e o individualismo liberal. In: WEFFORT, Francisco (Org.). Os clássicos da política, v. 1. 14. Ed. São Paulo: Ática, 2006, p. 79-110.

POLIN, Raymond. Indivíduo e comunidade. In: QUIRINO, Célia Galvão; SOUZA, Maria Teresa Sadek R. de. O pensamento político clássico; Maquiavel, Hobbes, Locke,

Montesquieu, Rousseau. São Paulo: T. A. Queiroz, 1980, p. 131-164.

RIBEIRO, Renato Janine. Hobbes: o medo e a esperança. In: WEFFORT, Francisco (Org.). Os clássicos da política, v. 1. 14. Ed. São Paulo: Ática, 2006, p. 51-78.

RODRIGUEZ, José Rodrigo (Coord.). O método de leitura estrutural. Cadernos Direito GV, São Paulo, v. 4, n. 2, p. 01-41, mar. 2007.

SANDEL, Michael J. Justiça - o que é fazer a coisa certa. Trad. Heloísa Matias e Maria Alice Máximo. 25. Ed. Rio de Janeiro: Civilização Brasileira, 2018.

SAYEG, Ricardo; BALERA, Wagner. O capitalismo humanista: filosofia humanista de direito econômico. Petrópolis: KBR, 2011. 